\title{
НЕ СЛЕДУЕТ УМАЛЯТЬ ЗНАЧЕНИЕ АДМИНИСТРАТИВНОГО ПРОЦЕССА РЕЦЕНЗИЯ НА МОНОГРАФИЮ М.А. ЛАПИНОЙ «АДМИНИСТРАТИВНАЯ ЮРИСДИКЦИЯ В СИСТЕМЕ АДМИНИСТРАТИВНОГО ПРОЦЕССА॥ (М.: ФИНАНСОВЫЙ УНИВЕРСИТЕТ, 2013. 140 с.)
}

\begin{abstract}
Аннотация: в рецензии отмечается, что сегодня нужны не фолианты, основанные на сплошном цитировании или на пересказе своими словами и парафразе норм административного законодательства. Нет, ныне очень востребованы такие пособия новой генерации, которые позволяли бы дать концептуальное осмысление (а в чем-то и переосмысление) и фундаментальное понимание административного права и административного процесса, системно интерпретировали бы основные понятия этой науки на более высоком (чем общеупотребимо) уровне научного качества. В рецензии отмечается, что сегодня нужны не фолианты, основанные на сплошном цитировании или на пересказе своими словами и парафразе норм административного законодательства. Нет, ныне очень востребованы такие пособия новой генерации, которые позволяли бы дать концептуальное осмысление (а в чем-то и переосмысление) и фундаментальное понимание административного права и административного процесса, системно интерпретировали бы основные понятия этой науки на более высоком (чем общеупотребимо) уровне научного качества. в рецензии отмечается, что сегодня нужны не фолианты, основанные на сплошном цитировании или на пересказе своими словами и парафразе норм административного законодательства. Нет, ныне очень востребованы такие пособия новой генерации, которые позволяли бы дать концептуальное осмысление (а в чем-то и переосмысление) и фундаментальное понимание административного права и административного процесса, системно интерпретировали бы основные понятия этой науки на более высоком (чем общеупотребимо) уровне научного качества.
\end{abstract}

Ключевые слова: прочесс, производство, юрисдикция, процедура, контроль, регулирование, власть, ответственность, стадия, принцип.

$\mathbf{y}$ каз Президента Российской Федерации от 7 мая 2012 г. № 601 «Об основных направлениях совершенствования системы государственного управления», прочие нормативные правовые акты, определяющие приоритетные направления административной реформы, но прежде всего - происходящая на наших глазах реорганизация российской судебной системы, - все это определяет необходимость нового научного взгляда на реалии и пути развития отечественного административного права и административного законодательства, детерминирует необходимость глубокого переосмысления теоретических стандартов административно-правового регулирования и стандартов преподавания административного права.

В 2013 г. вышла в свет научная монография авторитетного российского правоведа Марины Афанасьевны Лапиной, доктора юридических наук, профессора, заведующей кафедрой «Административное и информационное право» Финансового университета при Правительстве Российской Федерации.

М.А. Лапина совершенно справедливо отмечает, что наука административного права и процесса является наиболее востребованной областью юридических знаний, однако в этой науке наблюдается слабая либо недостаточная разработанность наиболее значимых проблем, выступающих в качестве объектов исследования науки административного права и процесса; при этом на фоне модернизации управленческих процессов, происходящих в системе государственного управления, административный процесс выходит на ведущее место. (с. 124-125).

Сегодня нужны не фолианты, основанные на сплошном цитировании или на пересказе своими словами и парафразе норм административного законодательства. Нет, ныне очень востребованы та- 
кие пособия новой генерации, которые позволяли бы дать концептуальное осмысление (а в чем-то и переосмысление) и фундаментальное понимание административного права и административного процесса, системно интерпретировали бы основные понятия этой науки на более высоком (чем общеупотребимо) уровне научного качества.

Соглашаясь с Ю.Н.Стариловым и А.В.Мартыновым в том, что «обрывочное, бессистемное, фрагментарное (как будто, ориентированное на подготовку именно практиков) обучение и соответственно познание административного права на самом деле создает основу для «шпаргалочного» изучения этой дисциплины», мы считаем, что именно работы, подобные рецензируемому труду М.А. Лапиной, и позволят сегодня перейти на качественно новые уровень подготовки отечественных юристов - административистов. Их изучение позволит выйти за рамки порочного круга натаскивания студентов на примитивизированное понимание (скорее, зазубривание) поверхностных моментов административного права.

Рецензируемое издание приятно удивляет хорошим сочетанием его относительно небольшого объема и ёмкости представленного в нем научного материала, насыщенностью глубокими осмыслениями и обобщениями. При этом работа М.А. Лапиной представляет собой и научную монографию, и ценное пособие для обучающихся административному праву, является уникальным изданием, в котором сделана серьезная попытка всесторонне рассмотреть сложнейший комплекс актуальных вопросов административного права и процесса.

Монография М.А. Лапиной содержит очень глубокие размышления о важнейших административно-правовых проблемах, задавая эталонный образец критического научного анализа. По существу, это несколько более расширенный мощный академический доклад о проблемах и новациях в науке.

При этом несомненным достоинством работы следует признать не только очень глубокое знание автором широчайшего спектра конкретных научно-теоретических и научно-практических проблем, но и рассмотрение их с самых разных углов зрения, в комплексе, используя самый разнообразный научный инструментарий.

\footnotetext{
1 Старилов Ю.Н., Мартынов А.В. Модернизация административного права как учебной дисциплины в условиях реформирования системы высшего профессионального образования // Вестник ВГУ, сер. «Право». - 2011. - № 2. C. $10-36 .-$ C. 27.
}

Мы находим важным отметить, что рецензируемая монография представляет собой очередной мощный столп в фундаменте разработанной и далее разрабатываемой М.А. Лапиной крупной интегральной концепции системы административного процесса. Другие концептуальные обеспечительные построения авторства М.А. Лапиной в утверждение и развитие этой ее интегральной концепции были опубликованы в научных журналах «Вопросы экономики и права» и «Юридический мир», прозвучала на организованной этим автором Всероссийской научно-практической конференции «Административная юрисдикция» 2012 года.

Главы первая и вторая рецензируемой монографии представляются нам центральными. Именно в этих главах своей монографии М.А. Лапина с присущей ей дотошностью, можно даже сказать - скрупулезностью, разбирает ключевые особенности административной юрисдикции в системе административного процесса, сущность административного процесса, особенности его системы и структурных элементов, а также исследует понятие, содержание и признаки административной юрисдикции, характерные признаки административно-юрисдикционной деятельности, основания, онтологию и значимые характеристики института административной юрисдикции.

В этих главах автор на основе собственной оригинальной научной концепции систематизирует существующие научные знания, подходы, последние изменения в административном законодательстве и свежие наработки судебной практики, по-новому концептуализируя исследуемую сферу знаний. М.А. Лапина активно привлекает не только комплиментарные, но еще больше - оппонирующие точки зрения различных авторов, в том числе советского периода, наглядно показывая поле распределения научных точек зрения по ключевым моментов исследуемой проблематики. Это чрезвычайно важно, поскольку наглядно позволяет на острие научной дискуссии уловить тончайшие моменты научных интерпретаций тех понятий, без надлежащего осмысления которых студент просто не сумеет стать юристом-административистом, а ученый-административист не получил бы тех импульсов к развитию своих собственных концептуальных подходов, каковые он получает по прочтении данной замечательной научной монографии.

Неподдельный интерес вызывает глава третья, посвященная систематизации знаний об основных виды административно-юрисдикционных производств. Она как бы объективирует в практической 
плоскости те теоретико-концептуальные подходы, те сформулированные авторов концептуальные построения, что наполнили первые две главы.

Несомненно ценны авторские размышления о проблемах преподавания административного права и процесса, в частности о недостатках существующих учебных пособий в этой части, а также авторские мысли относительно системы подготовки научных кадров в этой сфере, в том числе о недостатках паспорта новой профильной научной специальности (стр. 9-16 и проч.).

Полновесное рассмотрение теоретических новаций, которыми буквально наполнена досконально изученная нами монография М.А. Лапиной, заняло бы многие десятки страниц. И в настоящей рецензии мы вынуждены от этого отказаться лишь ради того, чтобы не смазать потенциальному читателю, коих круг довольно велик, ожидание и впечатление от прочтения этой объективно очень замечательной книги.

До́лжно отметить, что язык автора одновременно и научен, и доступен для понимания. Рационально спроектированные иллюстрации (на стр. 17, 39, 45 и др.) дают необходимое понимание ключевых содержательных моментов, и это показывает понимание М.А. Лапиной, что читать её книгу будут не только крупные ученые, но и те, кому еще только предстоит кем-то стать, чего-то добиться в науке и практике административного права и процесса.

Очевидно, что такого научного уровня монография признанного ученого-административиста не мыслима без каких-то суждений, которые могут и даже просто должны вызвать научную дискуссию. Ряд положений автора способны настроить читателя на дискуссию, и это придает труду М.А.Лапиной дополнительные очки.

Едва ли у нас с автором рецензируемой монографии есть какие-то радикальные, полярно несовместимые расхождения в фундаментальных позициях, но и соглашаться со всеми ее суждения мы тоже едва ли можем, более того - с рядом ее суждений мы можем согласиться только условно.

В частности, сложно в полной мере принять широкую трактовку автора, согласно которой административный процесс - это урегулированную административно-процессуальными нормами деятельность, направленную на разрешение индивидуальных дел в сфере государственного управления уполномоченными на то органами исполнительной власти Российской Федерации, а в предусмотренных законом случаях и другими пол- номочными субъектами административно-процессуальных отношений (стр. $19-20)$.

Все-таки представляется, что используя термин «процесс» следовало бы говорить лишь о деятельности судов, связанной непосредственно с отправлением правосудия, применительно к рассматриваемой сфере общественных отношений.

Однако, скорее всего, данное несогласие связано в первую очередь с профессиональным правосознанием автора данной рецензии, уже более восьми лет рассматривающего в качестве судьи арбитражного суда дела, возникающие из административных и иных публичных правоотношений.

Признаюсь, что многие часы были проведены в научных дискуссиях с М.А. Лапиной, и все обсуждавшиеся вопросы здесь просто не уместить. Впрочем, едва ли профессор М.А. Лапина и потребовала такого «соглашательства».

«Если мне и не удастся убедить своих противников в правоте защищаемых мною принципов, то я, по крайней мере, дам им необходимые сведения для того, чтобы возражать мне. Одного этого результата достаточно для оправдания предпринятой мною работы», - писал великий русский ученый и врач И.И. Мечников в своей книге «Невосприимчивость в инфекционных болезнях».

Сегодня, к сожалению, правовая наука по большей своей части обращена назад, в прошлое, либо же следует по пятам за политикой государства, за свершениями в рамках законодательного процесса, в лучше случае - что-то критикуется. Но научных работ, бросающих вызов слишком долго уже устоявшимся, закостенелым догматам, весьма и весьма мало, прискорбно мало. Такие работы, как монография М.А. Лапиной встретишь откровенно редко.

Но как писал Роланд Левински, «вузам следует бросать вызов устоявшимся идеям и стимулировать дебаты в обществе» ${ }^{2}$.

Крайне важен для любого серьезного исследования в административном праве перспективный анализ. Да хотя бы уже и потому, что, как говаривал Чарльз Кеттеринг, «Я интересуюсь будущим потому, что собираюсь провести там всю оставшуюся жизнь»... Книга М.А. Лапиной позволяет заглянуть «за горизонт».

Научная монография М.А. Лапиной «Административная юрисдикция в системе административного процесса» подготовлена с большим творческим вдохновением и научным энтузиазмом, является концептуально цельной, завершенной фундамен-

2 The Independent, 29 May 2003. 
тальной работой, в которой представлен комплексный подход к изучению заявленного круга проблем. Работа характеризуется большим теоретическим и практическим значением, содержит новые для науки административного права и процесса концептуальные построения, обеспечивающие существенное приращение научного знания, систематизацию идей о направлениях и приоритетах развития российского административного законодательства.

Сказанное выше дает нам даже не столько надежду, сколько твердую уверенность, что книга за- ймет достойное ее место в сокровищнице российской административно-правовой научной мысли и будет востребована не только уже сложившимися правоведами-административистами. А для студентов, магистрантов и аспирантов, только осваивающих эту науку, рецензируемая монография явится просто мастер-классом - и по части того, что следует знать в административном праве и административном процессе, и по части того, как образцово следует писать научные работы в рамках этой науки.

\section{Библиография:}

1. Старилов Ю.Н., Мартынов А.В. Модернизация административного права как учебной дисциплины в условиях реформирования системы высшего профессионального образования // Вестник ВГУ, сер. «Право». - 2011. - №

2. The Independent, 29 May 2003.

3. Куракин А.В., Костенников М.В. Административный процесс и его реализации в деятельности полиции // NB: Российское полицейское право. - 2013. - 4. - C. 1 - 44. URL: http://www.e-notabene.ru/ pm/article_9250.html

4. Костенников М.В. К вопросу о некоторых актуальных проблемах административного права // NB: Административное право и практика администрирования. - 2013. - 4. - C. 71 - 95. URL: http:// www.e-notabene.ru/al/article_8840.html

5. Иодковский Э.В. Решения Европейского суда по правам человека в системе источников гражданского процессуального права // Актуальные проблемы российского права. - 2011. - 4. - С. 130 - 141.

\section{References:}

1. Starilov Yu.N., Martynov A.V. Modernizatsiya administrativnogo prava kak uchebnoi distsipliny v usloviyakh reformirovaniya sistemy vysshego professional'nogo obrazovaniya // Vestnik VGU, ser. «Pravo». — 2011. — №

2. The Independent, 29 May 2003.

3. Kurakin A.V., Kostennikov M.V. Administrativnyi protsess i ego realizatsii v deyatel'nosti politsii // NB: Rossiiskoe politseiskoe pravo. - 2013. - 4. - C. 1 - 44. URL: http://www.e-notabene.ru/pm/article_9250.html

4. Kostennikov M.V. K voprosu o nekotorykh aktual'nykh problemakh administrativnogo prava // NB: Administrativnoe pravo i praktika administrirovaniya. - 2013. - 4. - C. 71 - 95. URL: http://www.e-notabene.ru/ al/article_8840.html

5. Iodkovskii E.V. Resheniya Evropeiskogo suda po pravam cheloveka v sisteme istochnikov grazhdanskogo protsessual'nogo prava // Aktual'nye problemy rossiiskogo prava. - 2011. - 4. - C. $130-141$. 